sciendo

DOI: $10.2478 /$ sjpna-2019-0002

\title{
RESEARCH ON THE RESPONSES OF THE HYBRID POWER SYSTEM BASED ON ENERGY PROFILES
}

\section{Arkadiusz Adamczyk ${ }^{\circledR}$}

Polish Naval Academy, Faculty of Mechanical and Electrical Engineering, Śmidowicza 69 Str., 81-127 Gdynia, Poland; e-mail: a.adamczyk@amw.gdynia.pl; ORCID ID 0000-0001-6492-4411

\begin{abstract}
The article contains the chosen results of research on the use of energy profiles controlling the operation of a group of devices powered by a hybrid power source. The concept of using alternative energy sources allows to reduce the total weight of the power system and model its behavior during work. Modern fuel cells are characterized with a very high energy density to mass ratio $[\mathrm{Wh} / \mathrm{kg}]$, and the additional cooperation of supercapacitors and lithium-ion batteries supporting their operation ensures continuous operation and the required dynamics response while maintaining a low mass of the power supply system. The author presented the general configuration of the layout model, as well as the results of tests of individual elements included in the physical implementation of the hybrid power system.
\end{abstract}

Key words:

hybrid power source, fuel cell, supercapacitor, power management.

Research article

(C) 2019 Arkadiusz Adamczyk This is an open access article licensed under the Creative Commons Attribution-NonCommercial-NoDerivatives 4.0 license (http://creativecommons.org/licenses/by-nc-nd/4.0/) 


\section{INTRODUCTION}

In modern scientific literature, we can meet a large number of publications on the use of fuel cells in practical applications $[3,7,8,11]$. Due to the characteristics of the cells, they often concern such areas as automotive [5] or emergency power supply [5]. The authors have noticed the disadvantages of the fuel cell, which can be eliminated thanks to the cooperation of several types of cells. Such hybrid systems provide significant savings in the mass of vehicles powered by them. However, there are few studies, aimed at using this type of solution in powering mobile devices $[6,10]$. With the miniaturization of this type of system, you can encounter many difficulties. Elements such as transducers, cooling systems and the cells themselves on solutions that do not require miniaturization are characterized by greater efficiency and their working parameters allow to extend their life. Mobile applications force the designers to minimize the mass and size of such systems, which has certain consequences.

Author decided to use a PEM fuel cell (Proton Exchange Membrane Fuel Cell) in cooperation with a battery and a supercapacitor. By properly selecting the parameters of individual elements, one can achieve significant weight savings compared to currently used primary or secondary cells while maintaining the same energy parameters as was presented in [2].

The subject of energy profiles and their genesis has been described in more detail [1]. Energy profiles allow to take under consideration not only for the prediction of energy demand but also the dynamics of the hybrid system. The use of information coming from energy profiles requires a power management system that, based on control algorithms, determines the quasi-optimal work cycles of the cells. This algorithm takes into account information resulting from the energy profile, i.e. both the type of load, working time and instantaneous parameters of individual cells. During the analysis of the hybrid power system operation, two types of energy profile generations were used - predefined and random. Due to the uniqueness of the waveforms

and the increased electricity consumption resulting from the final energy balance, the author decided to apply energy profiles generated randomly to examine the physical object. These tests allow for the hybrid power source to receive the most 'adverse' extortion from the point of view of total energy demand. All types of energy profiles have been prepared taking into account the exceptions resulting from the specificity of tasks assigned to the environment in which the operator is located. The generation of profiles has been prepared using a program written in the MATLAB computer 
environment. Profiles were initially tested using the SIMULINK simulation environment (MATLAB), which was the basis for research on a physical object.

\section{HYBRID BATTERY MODEL}

According to earlier assumptions, the hybrid power source was designed based on three current sources (fig. 1) where one can find such elements as:

- Stab - DC-DC converter 'A';

- Measurement block - measuring system 'B';

- Load charge switch - logic and control system 'C';

- Logic - logic block 'D';

- Supercap - a battery of supercapacitors with measuring elements 'E',

- Batt - li-ion battery with measuring elements ' $F$ ';

- Fuel cell - fuel cell with measuring elements ' $G$ '.

The main source is a PEM type fuel cell, the energy source of which is hydrogen supplied with the help of hydrogen accumulators in metal hydrides. The actual parameters of the fuel cell used are shown in the characteristics (fig. 2).

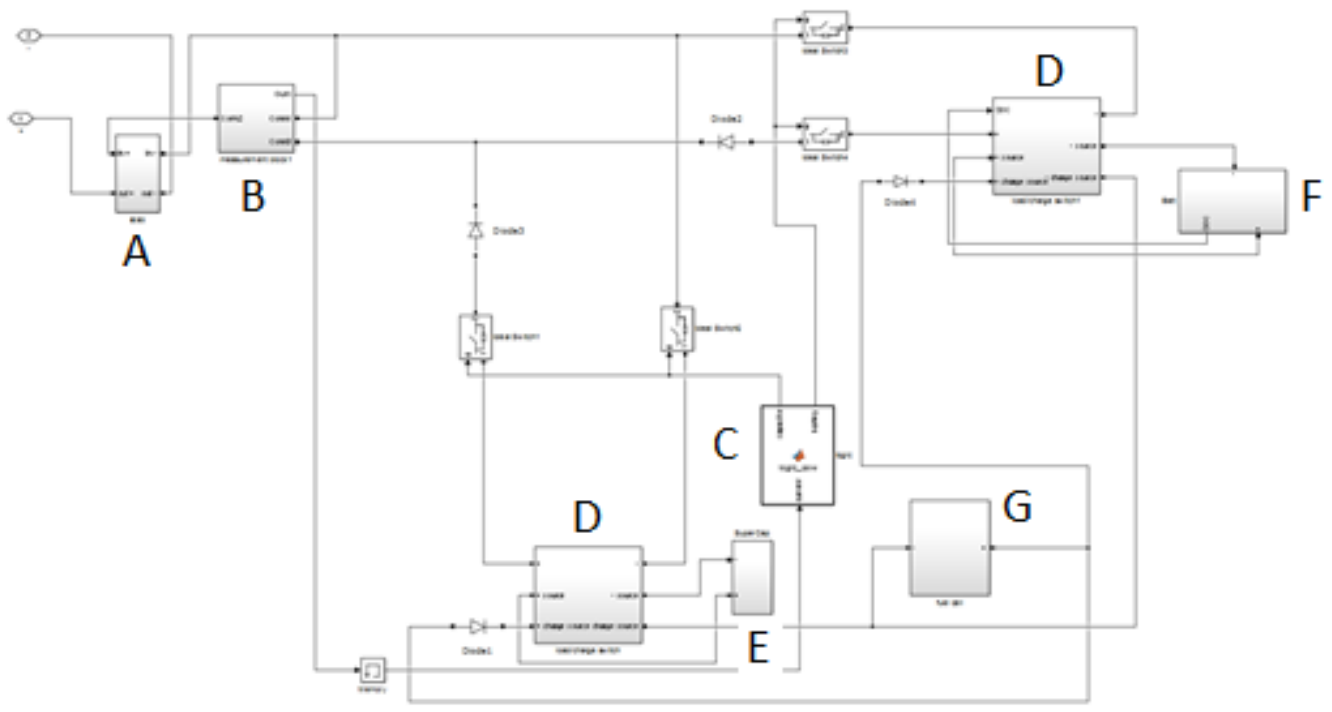

Fig. 1. Block schematic of a hybrid battery source in the MATLAB environment 
Author decided to use the PEMFC fuel cell model implemented in the Matlab environment. Due to the possibility of adjusting the parameters determining the dynamics of operation and modification of the current-voltage characteristics, this model is a sufficient approximation. The use of more complicated approximations causes unnecessary extension of the simulation without affecting the accuracy of the results.

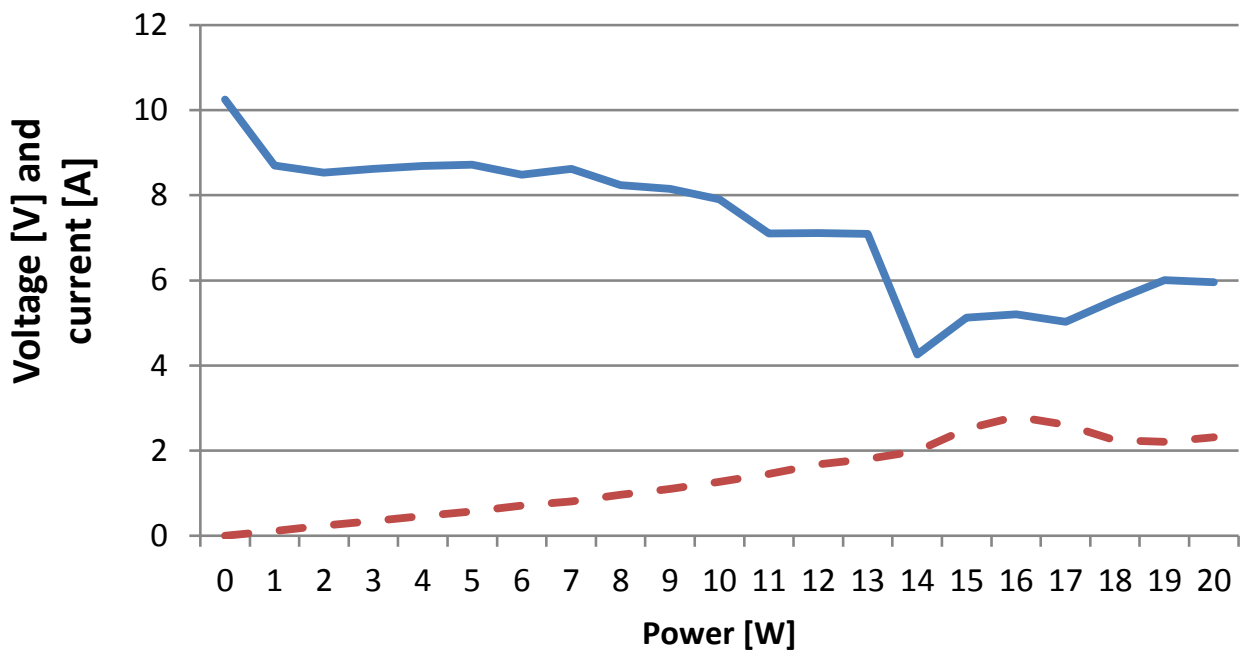

Fig. 2. Current and voltage characteristics as a function of the load power of the HORIZON $20 \mathrm{~W}$ fuel cell used to build the physical model of the hybrid power system (author measurements), where solid line - voltage, dashed line - current

Fuel cell is the main source of electricity due to the most advantageous energy density among the energy sources applied in this work. Working along with a lithium-ion battery and supercapacitors, it was possible to minimize fuel cell's disadvantages, that are the response time during startup and operation outside the optimal area.

Another element of the hybrid power supply system was a battery pack designed in lithium-ion technology with a capacity of $5 \mathrm{Ah}$. The cells used for testing were Panasonic NCR-18650B with a voltage of $3.7 \mathrm{~V}$ each. This connection provides a rated voltage of $7.2 \mathrm{~V}$. The discharge characteristics of a single cell (fig. 3 ) were plotted based on measurements made by the author with the Pulsar 3 device which is a regulated charge/discharge monitor with power range up to $1.5 \mathrm{~kW}$ and $25 \mathrm{~A}$. 


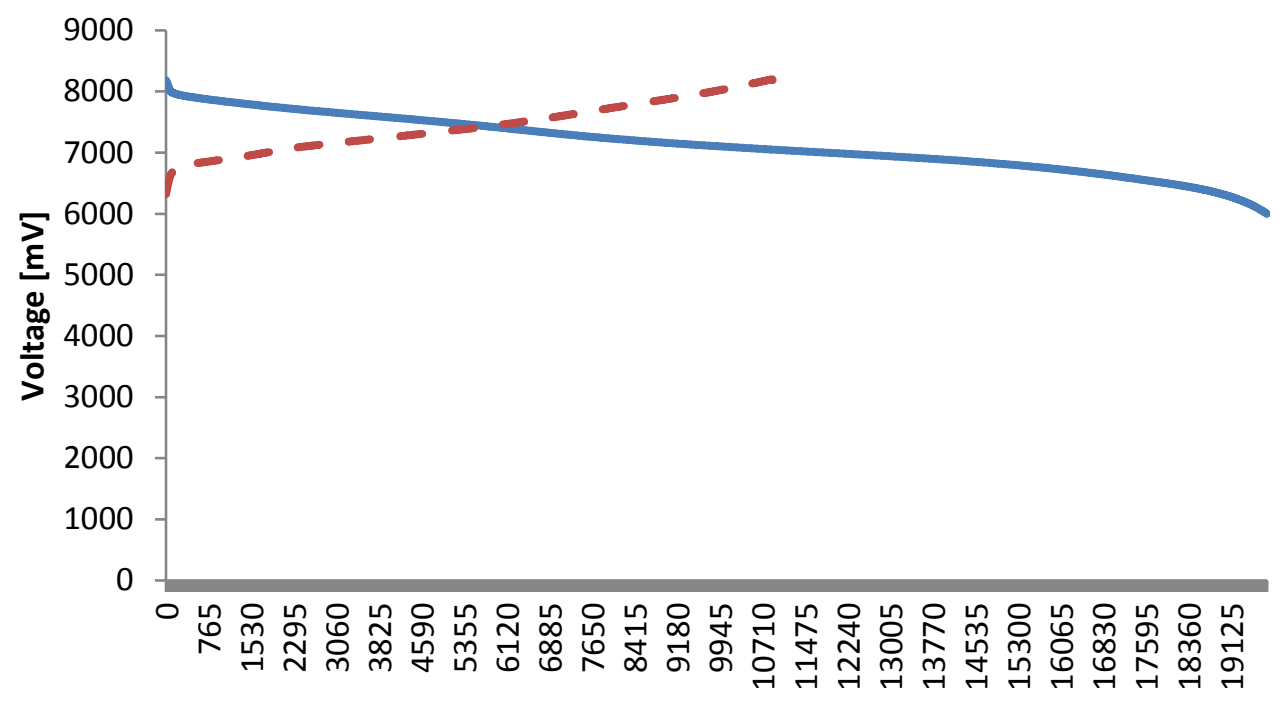

Time $[\mathrm{s}]$

Fig. 3. Lithium-ion battery discharge characteristics (author measurements), where solid line - discharge with 1 A current, dashed line - charging with 2 A current

Lithium-ion technology allows for cycles of charging and discharging avoiding the memory effect [4]. Battery operation is focused on the minimum power range, in which additionally the response time of the supply cell must be greater than the reaction time of the fuel cell. Battery operation threshold as and the SOC (State of Charge) limit value is defined in the algorithms responsible for controlling the operation of the hybrid battery.

As protection for instantaneous jumps in energy demand, a $5 \mathrm{~F}$ supercapacitors battery with a $24 \mathrm{~V}$ output voltage was used (fig. 4). This high rated voltage of the supercapacitor is the result of a series connection of two supercapacitors with a capacity of $10 \mathrm{~F}$. The capacitor bank does not have a balancer, therefore the operating range has been reduced to $12 \mathrm{~V}$ despite the possible $24 \mathrm{~V}$. The tested supercapacitors were used in the physical model.

As in the battery, the operating threshold is defined in the algorithms responsible for controlling the operation of the hybrid power supply system. The supercapacitor has been controlled in a way that does not allow its voltage to drop below the set threshold. The use of a supercapacitor provides an immediate response to rapid power fluctuations at the output of the power system. Moreover, it is characterized by a very high power density, number of charging and discharging cycles and a wide temperature range of operation, which is of great importance in mobile applications. 


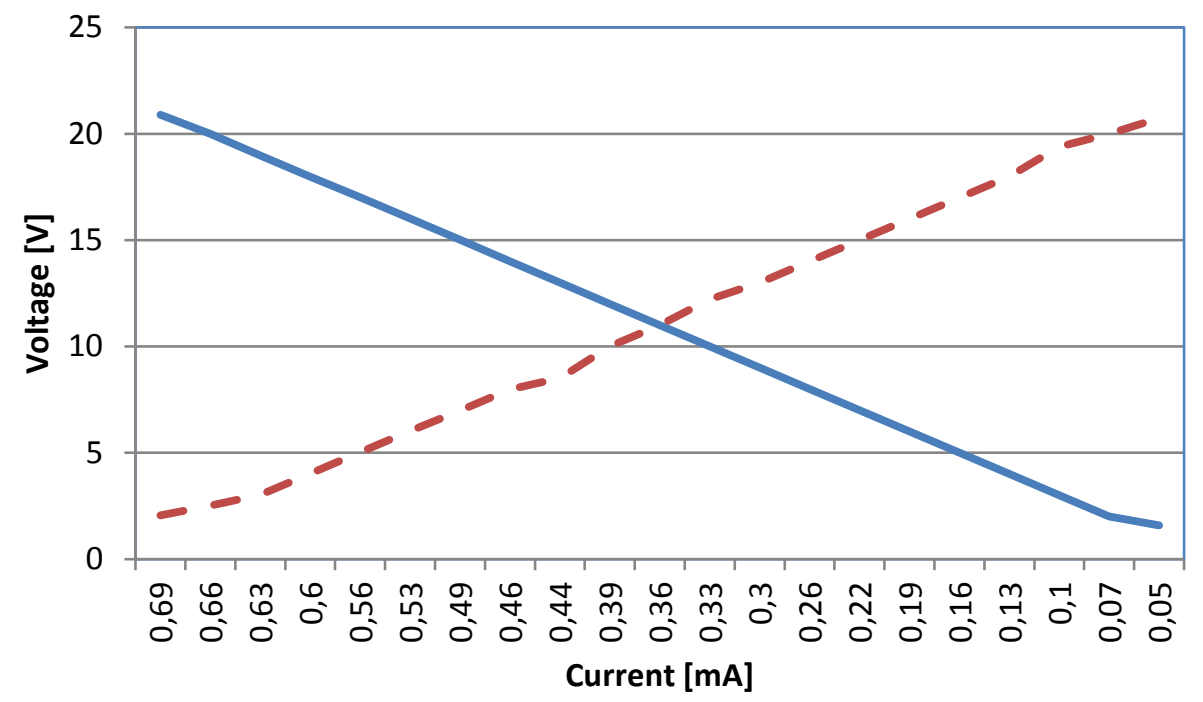

Fig. 4. Discharge and charging characteristics of VEC6R0 505QG type supercapacitors (author measurements), where solid line - discharge, dashed line - charge

\section{TEST RESULTS ON THE PHYSICAL MODEL}

Both the simulation model and the physical model were subjected to an electric load, the values of which varied according to the given scenario. Scenarios of activities were reflected by means of the energy profile (fig. 5). In the simulation part, the load function was a system of controlled resistances, selected so as to reproduce the electrical properties of simulated devices. While testing the operation of the physical model, the electronic load Array 3711A was used, the operation of which was controlled by the Labview program. Array $3711 \mathrm{~A}$ is programmable electronic load. It allows to change load parameters up to $300 \mathrm{~W}$ with $36 \mathrm{~V}$.

Fig. 6 and 7 show the current and voltage responses of the 5 Ah lithium-ion battery used in the physical model. The resulting battery operating limit, set at $0.2 \mathrm{~A}$, is clearly shifted above this threshold which was set by the hybrid power system operation algorithm. This is caused by the energy demand resulting from the use of control elements in the physical model. All electronic systems are powered directly from the battery, this is dictated by both the stability of the battery parameters and the reliability of power from the moment of switching on. 


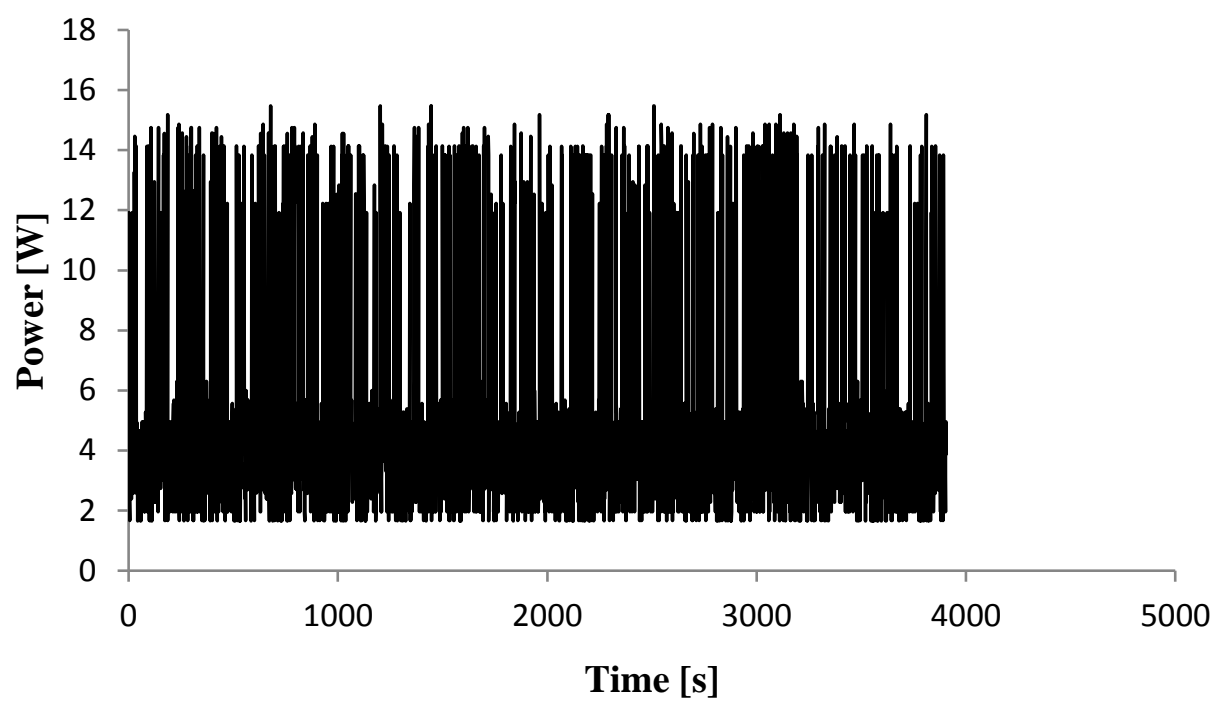

Fig. 5. A fragment of the energy profile corresponding to the sum of the loads of individual current sources

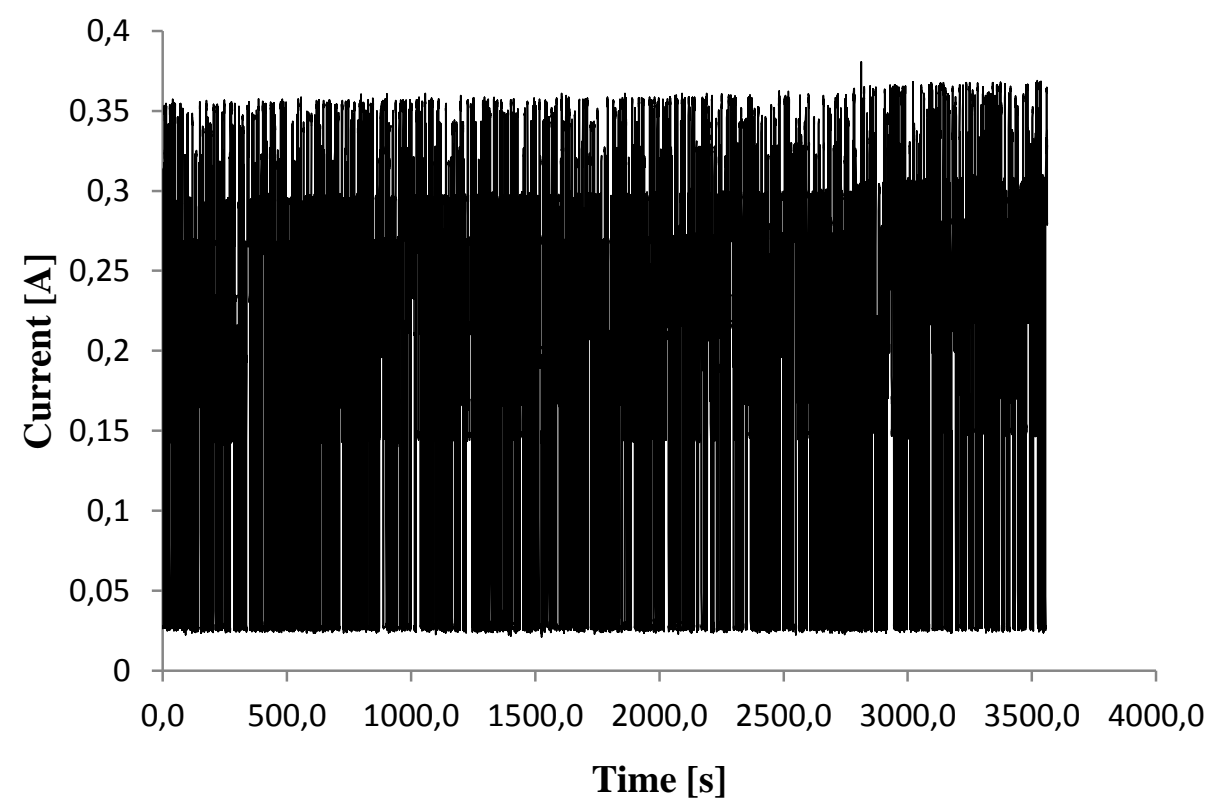

Fig. 6. Illustration of the battery current response during tests on a physical model 


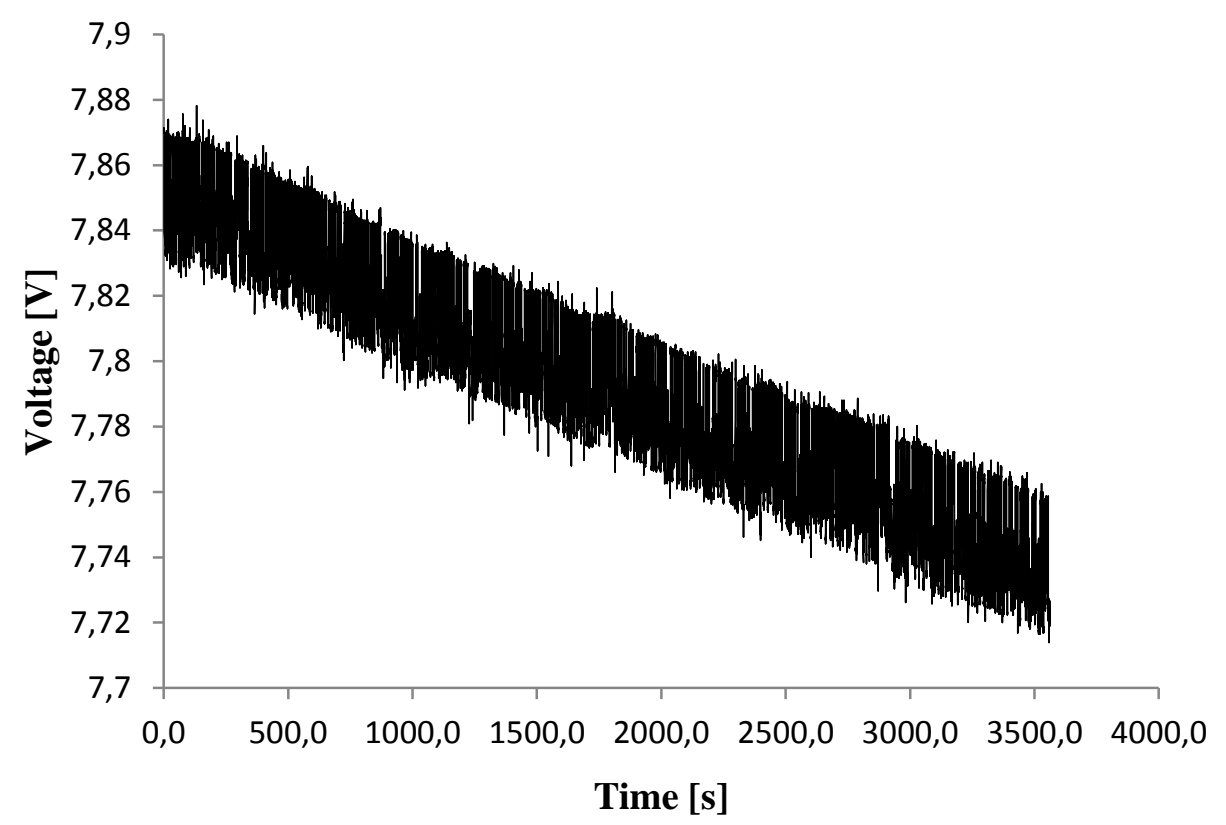

Fig. 7. Illustration of the battery voltage response during tests on a physical model

Analyzing the graphs illustrating the fuel cell's response to given loads (fig. 8 and 9), it can be noticed that the fuel cell does not reach its rated parameters. This corresponds to previous research of the Horizon 20 fuel cell made before the construction of the physical hybrid power system model (fig. 8).

The last of the tested sources in the hybrid power system is a supercapacitor, which task was to cooperate with the fuel cell. Illustrations with the current and voltage response of the supercapacitor (fig. 10 and 11) present its behavior. In the initial phase, the supercapacitor is charged using the energy provided by the fuel cell. After equalizing the voltage at the output of the fuel cell and supercapacitor, the supercapacitor is a kind of energy buffer. At the moment of cleaning the stack (cyclically) or delayed reaction of the fuel cell to the load (resulting from low dynamics), the supercapacitor takes over the electrical load directed to the fuel cell terminals. Comparing the characteristics of the fuel cell and the supercapacitor, one can see 'complementary' waveforms, which indicates their alternating work. In order to check the correctness of the joint operation of the described elements, an analysis of the output voltage at the terminals of the built-in DC-DC converter was carried out. The tests were carried out for all the action scenarios. The obtained results were very similar during all tests cycles. No voltage drops were found, and the values measured over the entire cycle fluctuated from 23.92 to $23.89 \mathrm{~V}$, which indicates a good voltage stability at the output of the system (fig. 12). 


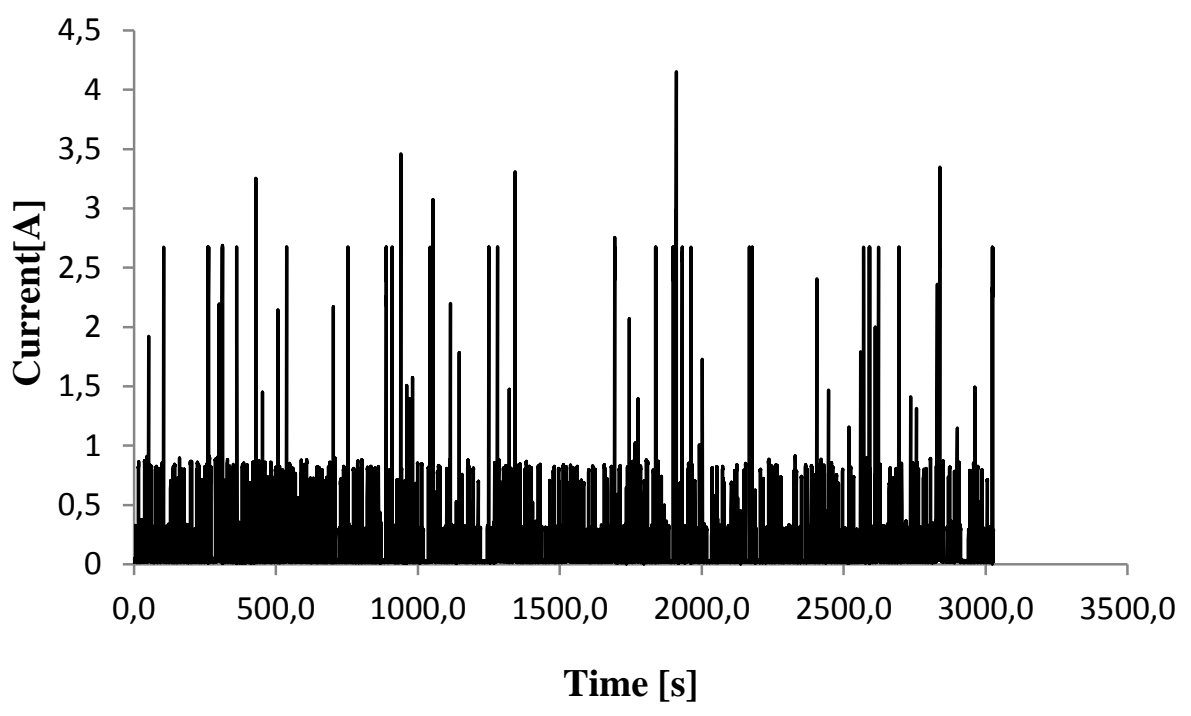

Fig. 8. Illustration of the fuel cell's current response during tests on a physical model

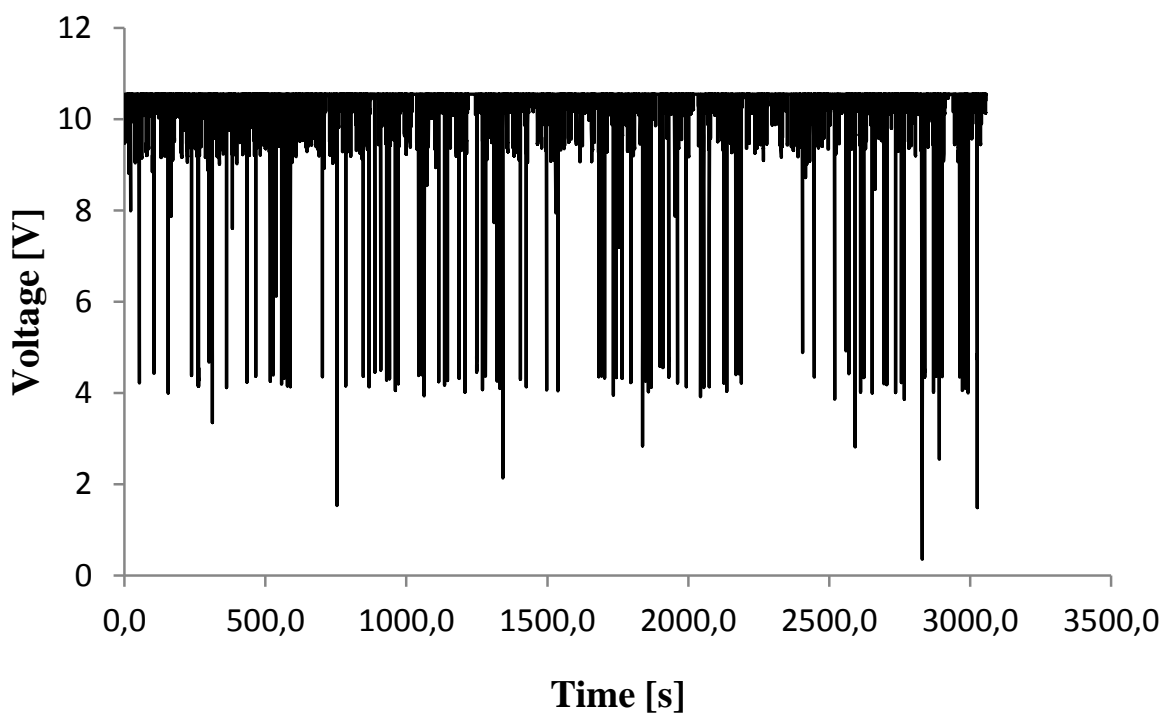

Fig. 9. Illustration of the fuel cell's voltage response during tests on a physical model 


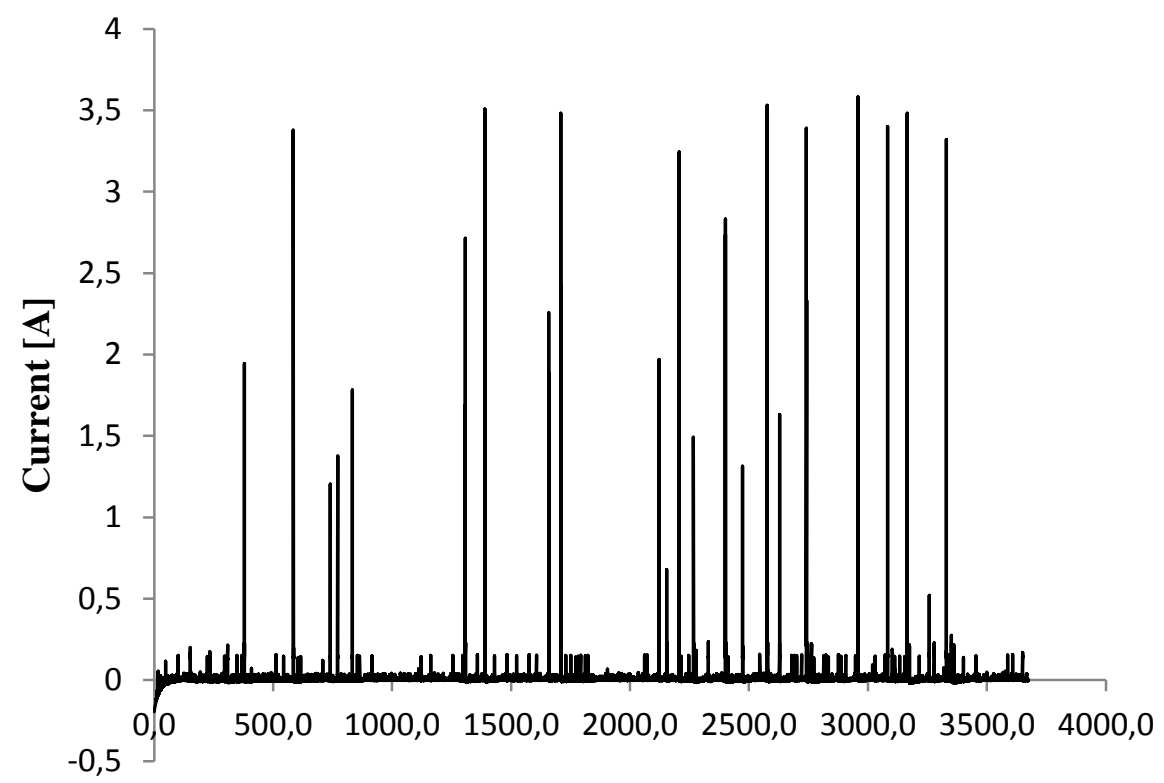

\section{Time [s]}

Fig. 10. Illustration of the supercapacitor current response during tests on physical model

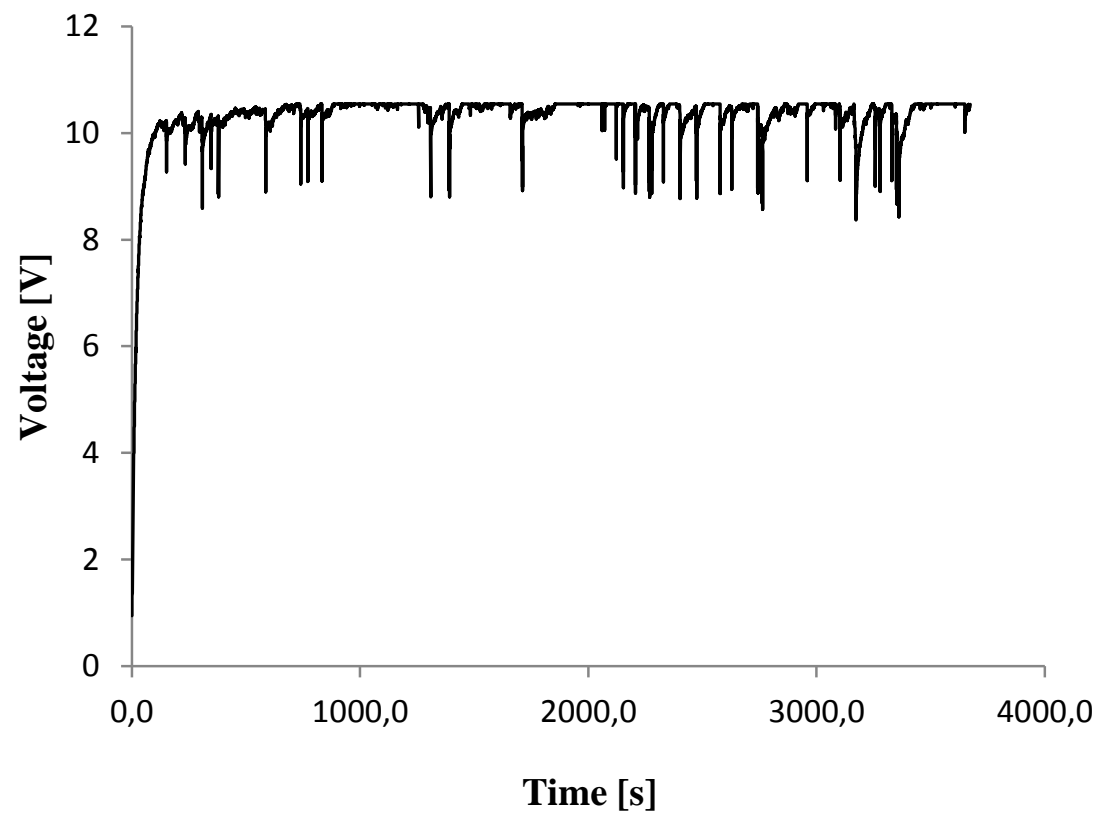

Fig. 11. Illustration of the supercapacitor voltage response during physical model tests 


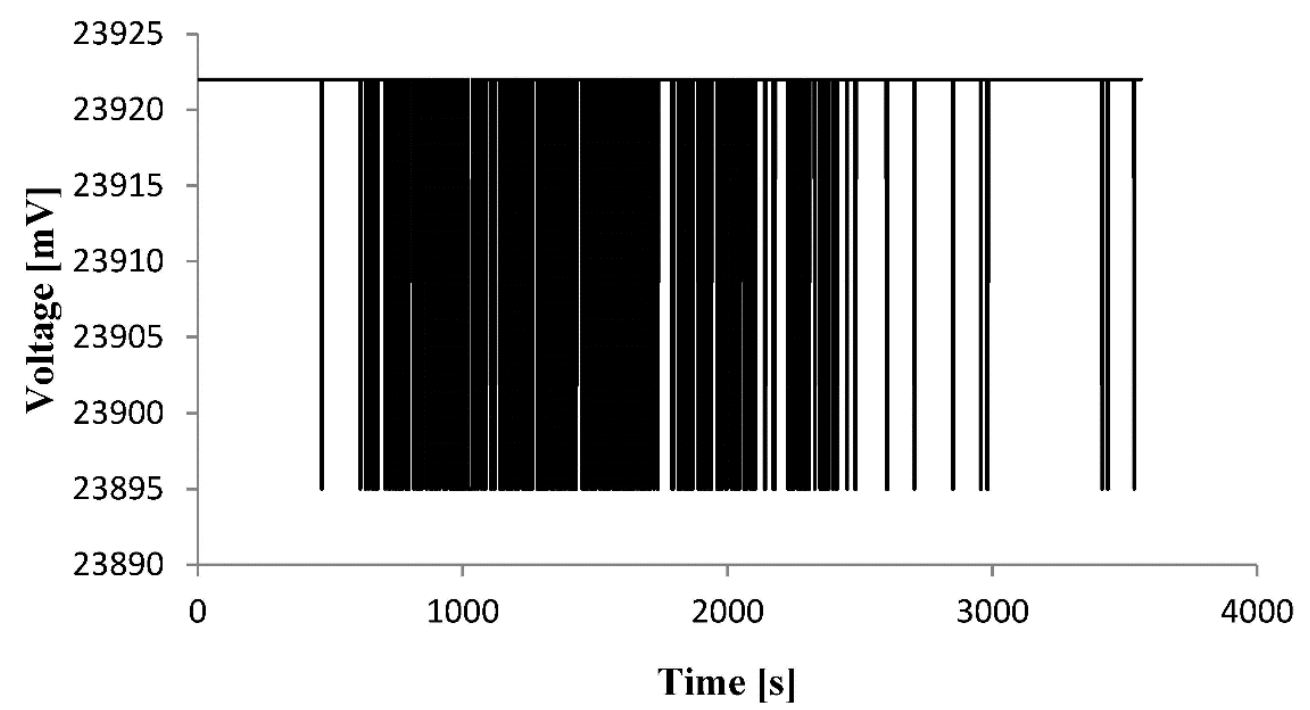

Fig. 12. The illustration of the output voltage in physical model of the hybrid power system during tests

\section{CONCLUSIONS}

The physical model of the hybrid power system meets the requirements and ensures uninterrupted operation of the connected load. The main energy expenditure was directed to the fuel cell, the dynamics of which were improved thanks to the use of two auxiliary cells in the form of a supercapacitor and a battery. The supercapacitor in cooperation with the fuel cell provides energy for momentary power demand jumps in the area of high power demand. The system in this form allows for any adjustment of the parameters of individual cells in order to optimize their dimensions for a specific application. In physical model those actions resumed in decent mas reduction, which will be shown in further publications. Changing the parameters will also allow for a different way of distributing the load between the individual cells. The physical model is also the basis for further modifications that will take into account the possibility of using Energy Harvesting.

\section{REFERENCES}

[1] Adamczyk A., Energy profiles as a method for minimizing weight of hybrid power supply systems, 'Zeszyty Naukowe Akademii Marynarki Wojennej - Scientific Journal of Polish Naval Academy', 2017, Vol. 208, No. 1, pp. 5-13, DOI:10.5604/0860889X.1237617. 
[2] Adamczyk A., Grzeczka G., Hybrid power supply system model for offshore floating platforms, 'Journal of Marine Engineering and Technology', 2017, Vol. 16, No. 4, pp. 392-399.

[3] Badwal S. P. S., Giddey S., Kulkarni A., Goel J., Basu S., Direct methanol fuel cells for transport and ststionary applications - a comprehensive review, 'Applied Energy', 2015, Vol. 145, pp. 80-103.

[4] Cope R., Podrazhansky Y., The art of battery charging, The Fourteenth Annual Battery Conference on Applications and Advances, Proceedings of the Conference held at California, 12-15 January 1999, pp. 233-237.

[5] Debe M. K., Electrocatalyst approaches and challenges for automotive fuel cells, 'Nature', 2012, Vol. 486, pp. 43-51.

[6] Dyer C. K., Fuel cells for portable applications, 'Journal of Power Sources', 2002, Vol. 106, Issue 1, pp. 31-34.

[7] Garche J., Jorissen L., Applications of Fuel Cell Technology: Status and Perspectives, "The Electrochemical Society', Interface, Summer 2015, [online], https://www.electrochem.org/dl/interface/ sum/sum15/sum15_p39_43.pdf [access 20.09.2018].

[8] Logan B. E., Regna M. J., Microbial fuel cells-challenges and applications, 'Environ. Sci. Technol.', 2006, 40 (17), pp. 5172-5180, DOI: 10.1021/es0627592.

[9] Motapon S., Dessaint L., Al-Haddad K., A comparative study of energy management for a fuel cell hybrid emergency power system of more electric aircraft, 'IEEE Transactions on Industrial Electronics', 2014, Vol. 61, Issue 3, pp. 1320-1334, DOI: 10.1109/TIE.2013.2257152.

[10] Singhal S. C., Solid oxide fuel cells for stationary, mobile, and military applications, 'Solid State Ionics', 2002, Vol. 152/153, pp. 405-410.

[11] Vielstich W., Lamm A., Gasteier H., Yokokawa H., Hanbook of fuel cells: fundamentals, technology and applications, Vol. 5-6, Wiley 2003.

\section{BADANIE ODPOWIEDZI HYBRYDOWEGO SYSTEMU ZASILANIA NA WYMUSZENIA PROFILAMI ENERGETYCZNYMI}

\section{STRESZCZENIE}

Artykuł zawiera wybrane wyniki badań nad wykorzystaniem profili energetycznych sterujących działaniem grupy urządzeń zasilanych hybrydowym źródłem zasilania. Koncepcja wykorzystania alternatywnych źródeł energii pozwala na zmniejszenie masy całkowitej układu zasilającego oraz modelowanie jego zachowania podczas pracy. Współczesne ogniwa paliwowe charakteryzują się bardzo dużym stosunkiem gęstości energii do masy [Wh/kg], a dodatkowa współpraca superkondensatorów oraz akumulatorów litowo-jonowych wspomagających ich działanie zapewnia ciągłą pracę oraz wymaganą dynamikę odpowiedzi przy zachowaniu niskiej masy układu zasilającego. 
Autor przedstawił ogólną konfigurację modelu układu oraz wyniki badań poszczególnych elementów wchodzących w skład fizycznej realizacji hybrydowego systemu zasilania.

\section{Słowa kluczowe:}

hybrydowe systemy zasilania, ogniwa paliwowe, superkondensator, zarządzanie energią.

Article history

Received: $\quad 25.09 .2018$

Reviewed: 27.02.2019

Revised: $\quad 27.03 .2019$

Accepted: 28.03.2019 